\title{
HOC VOLVMINE CONTINENTVR
}

Praefatio ……......................................................................... VII

1. De Iuliani operum post eius mortem fortuna ………....... viI

2. De Iuliani opusculis quae hac editione continentur …….. vII

3. De singulorum opusculorum traditione manuscripta ….... $\mathrm{x}$

4. De aliis textus Iulianei fontibus …………................... XVII

5. De editionibus prioribus …….................................... XVIII

6. De rationibus huius editionis et de Iuliani sermonis proprietatibus …….............................................. XXIV

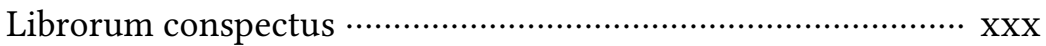

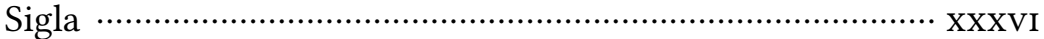

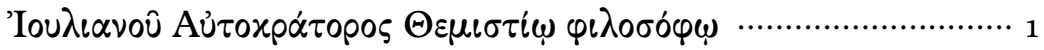

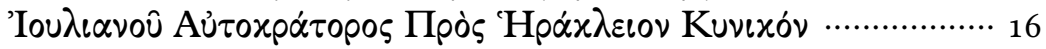

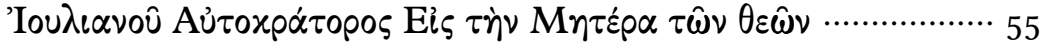

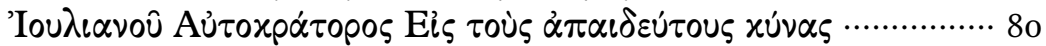

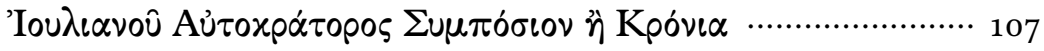

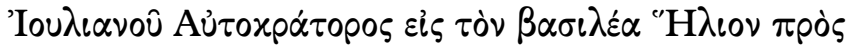

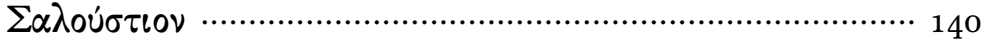

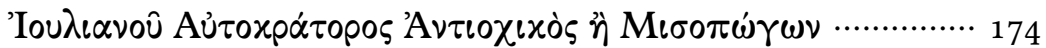

Index nominum propriorum ……………………………...... 215

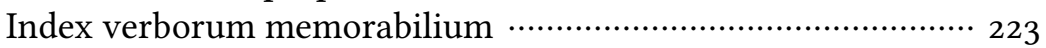


